\title{
Developing Students' Conceptual Understanding and Critical Thinking Through Dunia Hidrokarbon Games
}

\author{
Indah Sari* \\ Program Studi Pendidikan Kimia \\ Universitas Sultan Ageng Tirtayasa \\ Serang, Indonesia \\ *indahsari@untirta.ac.id
}

\author{
Ijang Rohman, Ratnaningsih Eko Sardjono \\ Departemen Pendidikan Kimia \\ Universitas Pendidikan Indonesia \\ Bandung, Indonesia
}

\begin{abstract}
Fun learning atmosphere is one of the important things in the learning process. Students need fun learning atmosphere especially when they learn lessons that are considered difficult. Chemistry is one of the subjects considered difficult. Many researchers try to create a fun learning atmosphere by applying educational games. This study aims to investigate the effect of using Dunia Hidrokarbon games on student's conceptual understanding about hydrocarbons and their critical thinking. This study is a sequence of Research and Development work. Participants who involved in this study were six high school students from Bandung city, West Java province, Indonesia. Rasch measurement modelling were utilized to analyze the data. The result shows that students' conceptual understanding about hydrocarbons and critical thinking abilities can be developed by applying Dunia Hidrokarbon games as learning tools. Students can understand concepts on hydrocarbon topics including: carbon atoms, determination of molecular formulas, structures, and names of alkanes, alkenes, and alkynes through Dunia Hidrokarbon games, but they do not understand the concept of structural isomers and position isomers. Students' critical thinking abilities focusing on a question and deciding on an action can be developed, but analyzing arguments, asking and answering questions of clarification and challenge can't be developed.
\end{abstract}

Keywords-hydrocarbons, conceptual understanding, critical thinking, games, digital literacy

\section{INTRODUCTION}

Digital games are not a brand new in our lives, but their existence is becoming more popular because it is not only used for entertainment, but also for educational purposes $[1,2]$. Digital games is a form of digital literacy practice [3-6].

Hydrocarbons are one of the topics in chemistry subjects in high school. There are three aspects should be learned in this topic include molecular formulas, molecular structures, and the name of hydrocarbons. Students should be able to connect these three aspects. This condition requires teachers to be able to design an effective learning process. Effective learning can occur by creating a fun learning atmosphere [7,8]. Games is one of the tools that can help create fun learning atmosphere because games provide challenges and feedback for students $[1,9,12]$. Games can motivate students to learn actively and enjoyable [2]. Previous research has shown that the use of games in chemistry learning has a positive impact on student learning outcomes, engagement, and motivation [13-16]. Games can also build students' critical thinking. Learning material that presented as a game, students are more eager to try to win it. The effort is a critical thinking process $[17,18]$.

The learning media that available in schools for learning hydrocarbons topic is a molecular model, namely molymod. Nevertheless, the use of molymod for gaming has its limitations. Each school only has one or two sets of molymod. This causes not all students to use molecular models in the classroom so that not all students can be actively involved in learning. Students are also unlikely to be burdened with buying molymod because the price of molymod is expensive. Therefore, along with the development of information and communication technology can be developed computer games similar to using molymod. This study is important to be done because computer games can facilitate every student in learning on hydrocarbon topics at a low cost. In addition, students can learn not only in the classroom, but also at home. Dunia Hidrokarbon is a computer game for learning hydrocarbons topic with two different way to play. Alkanes, alkenes, and alkynes games can be played by way of 'catch and go' and the isomers game can be played by way of 'drag and drop'. There has never been a game for hydrocarbon topics that has the characteristics of how to play it like the Dunia Hidrokarbon games.

\section{Methods}

This study is a sequence of Research and Development [19]. This study is a limited trial stage. The previous stage was the development of computer games, namely Dunia Hidrokarbon that designed to build conceptual understanding and critical thinking. Participants who involved in this study 
were six 10-grade high school students from Bandung city, West Java province, Indonesia. They have never studied the topic of hydrocarbons. The multiple choices items consist of 15 questions were utilized to investigate students' conceptual understanding about hydrocarbons topic. Table 1 list the conceptual understanding items.

TABLE I. CONCEPTUAL UNDERSTANDING ITEMS

\begin{tabular}{|c|l|c|}
\hline No. Items & \multicolumn{1}{|c|}{ Chemistry Concepts } & Coding \\
\hline 1. & Carbon atom & Q01 \\
\hline 2. & Structure of alkanes & Q02 \\
\hline 3. & Structure of alkynes & Q03 \\
\hline 4. & Molecular formula of alkenes & Q04 \\
\hline 5. & Name of alkanes & Q05 \\
\hline 6. & Molecular formula of alkanes & Q06 \\
\hline 7. & Structure of alkenes & Q07 \\
\hline 8. & Name of alkenes & Q08 \\
\hline 9. & Structure of alkynes & Q09 \\
\hline 10. & Molecular formula of alkynes & Q11 \\
\hline 11. & Structural isomers & Q12 \\
\hline 12. & Structural isomers & Q13 \\
\hline 13. & Structural isomers & Q14 \\
\hline 14. & Position isomers & Q15 \\
\hline 15. & Position isomers & \\
\hline
\end{tabular}

The multiple choices items consist of 17 questions were utilized to investigate students' critical thinking. Table 2 list the critical thinking items.

TABLE II. CRITICAL THINKING ITEMS

\begin{tabular}{|c|l|}
\hline No. Items & \multicolumn{1}{|c|}{ Critical Thinking Abilities } \\
\hline 1. & Analyzing arguments \\
\hline 12. & $\begin{array}{l}\text { Asking and answering questions of clarification and } \\
\text { challenge }\end{array}$ \\
\hline 3. & Analyzing arguments \\
\hline 4. & Deciding on an action \\
\hline 5. & Focusing on a question \\
\hline 6. & Analyzing arguments \\
\hline 7. & Deciding on an action \\
\hline 8. & Deciding on an action \\
\hline 9. & Deciding on an action \\
\hline 10. & Deciding on an action \\
\hline 11. & Deciding on an action \\
\hline 12. & Deciding on an action \\
\hline 13. & Analyzing arguments \\
\hline 14. & Analyzing arguments \\
\hline 15. & Analyzing arguments \\
\hline 16. & $\begin{array}{l}\text { Asking and answering questions of clarification and } \\
\text { challenge }\end{array}$ \\
\hline 17. & Analyzing arguments \\
\hline
\end{tabular}

Rasch measurement model were utilized to analyze the data.

\section{RESULTS AND DISCUSSION}

Dunia Hidrokarbon is a computer games that designed to build students' conceptual understanding and critical thinking. The chemistry concepts include carbon atoms, structures, molecular formula, and names of alkanes, alkenes, and alkynes, structural isomers, and position isomers. Critical thinking abilities include analyzing arguments, asking and answering questions of clarification and challenge, deciding on an action, and focusing on a question. Fig. 1 shows a part of Dunia Hidrokarbon games.

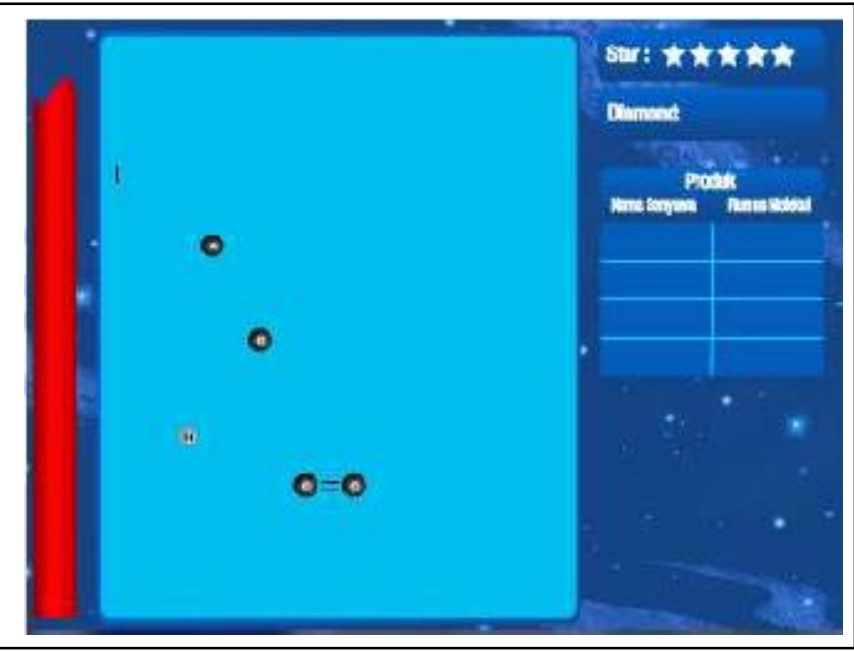

Fig. 1. Dunia Hidrokarbon games on alkenes challenge.

Students answer the conceptual understanding items and critical thinking items after they play Dunia Hidrokarbon games.

\section{A. Students' Conceptual Understanding}

The first study calculates the percentage of students' conceptual understanding. The purpose is to find out the percentage of students who answered correctly for each question. Fig. 2 shows the percentage of students' conceptual understanding.

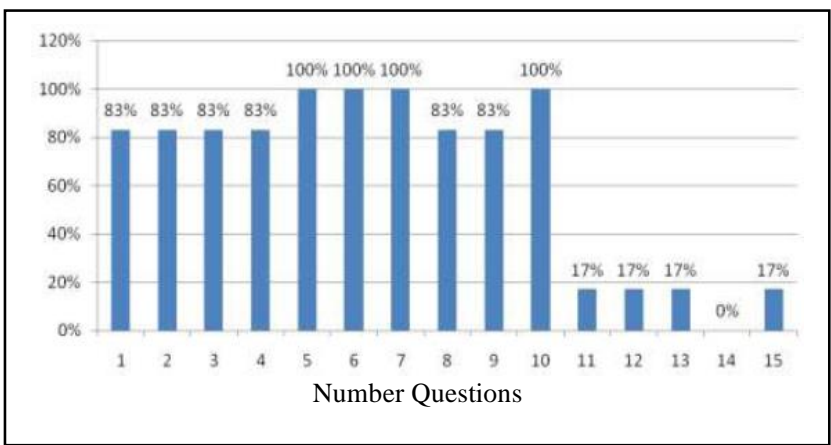

Fig. 2. Percentage of students' conceptual understanding

Fig. 2 shows that the percentage of students' conceptual understanding about carbon atoms, structures, names, and molecular formulas for alkanes, alkenes, and alkynes is more than $75 \%$. 


\begin{tabular}{|c|c|c|c|c|c|c|c|c|c|c|}
\hline & TOTAL & & & & Mooel. & & DuF & IT & outf1 & II \\
\hline & SCORE & count & MEAS: & & S.E. & & mose & $25 T 0$ & msQ & ZSTO \\
\hline MEAN & 9.7 & 15.8 & & .74 & 1.28 & & .67 & -.25 & .34 & -.31 \\
\hline SEM & 1.0 & .8 & & .27 & .18 & & .28 & .23 & .11 & .22 \\
\hline P.so & 2.2 & . & & .84 & .41 & & .45 & .52 & .24 & .48 \\
\hline 5.50 & 2.4 & .8 & & 11 & .45 & & .49 & .57 & .26 & .53 \\
\hline max. & 13.0 & 15.0 & & 11 & 1.83 & & 1.02 & .22 & .61 & .15 \\
\hline MLN. & 6.0 & 15.0 & & 37 & .86 & & .03 & -.97 & .63 & -98 \\
\hline Reat mose & 1.34 & TRUE SO & 2.50 & SEPA & MRATIOW & 1.86 & 6 Pers & ion $R \in C$ & asarury & .78 \\
\hline MDOEL RUSE & (E) 1.34 & TRUE SO & 2.50 & SEPA & RATIOA & 1.86 & 6 Pers & on RELI & ABAtIIT & 1.78 \\
\hline S.E. OF P & Person $M$ & EAN $=1.2$ & & & & & & & & \\
\hline $\begin{array}{l}\text { Son REA } \\
\text { WIBACH AL }\end{array}$ & $\begin{array}{l}\text { SCORE-T } \\
\text { LFHA (KR }\end{array}$ & $\begin{array}{l}\text { - MEASURE } \\
\text {-20) Pers }\end{array}$ & $\begin{array}{l}\text { OESELAT } \\
\text { RAW SC }\end{array}$ & $\begin{array}{l}\text { TION } \\
\text { CORE }\end{array}$ & $\begin{array}{l}-.99 \\
\text { TEST }\end{array}$ & RELIAS & ABILITY & -.77 & $\operatorname{sen}=1$ & 1.07 \\
\hline sumes & or of 10 & MEASURED & tes & & & & & & & \\
\hline & TOTAL & & & & mooel & & DiF & II & OUTF & II \\
\hline & SCORE & count & MEAS: & & S.E. & & mise & ZSTD & mose & ZSTO \\
\hline MEAN & 3.4 & 6.0 & & . .60 & 1.44 & & .87 & -.23 & .34 & -.27 \\
\hline SEM & .7 & .0 & & 12 & .en & & .26 & .34 & .10 & .13 \\
\hline P.SD & 2.0 & .0 & & 36 & .e3 & & .77 & 1.01 & $.3 e$ &, 38 \\
\hline 5.50 & 2.1 & .0 & & .54 & .84 & & .81 & 1.87 & .32 & .40 \\
\hline $\max$. & 5.0 & 6.0 & & 11 & 1.49 & & 2.47 & 1.50 & 1.60 & .47 \\
\hline MLE. & 1.0 & 6.0 & & .74 & 1,42 & & .29 & -90 & .13 & -.58 \\
\hline REAL MOSE & 1.65 & TRUE SO & 2.92 & SEPA & Rratiow & 1.77 & 7 Ites & RELI & IABfIITY & .76 \\
\hline Moot nose & 1.44 & TRUE SO & 3.83 & SEPA & MRATION & 2.10 & Iten & REU & IABILIT & .82 \\
\hline
\end{tabular}

Fig. 3. Summary statistic on Rasch analysis.

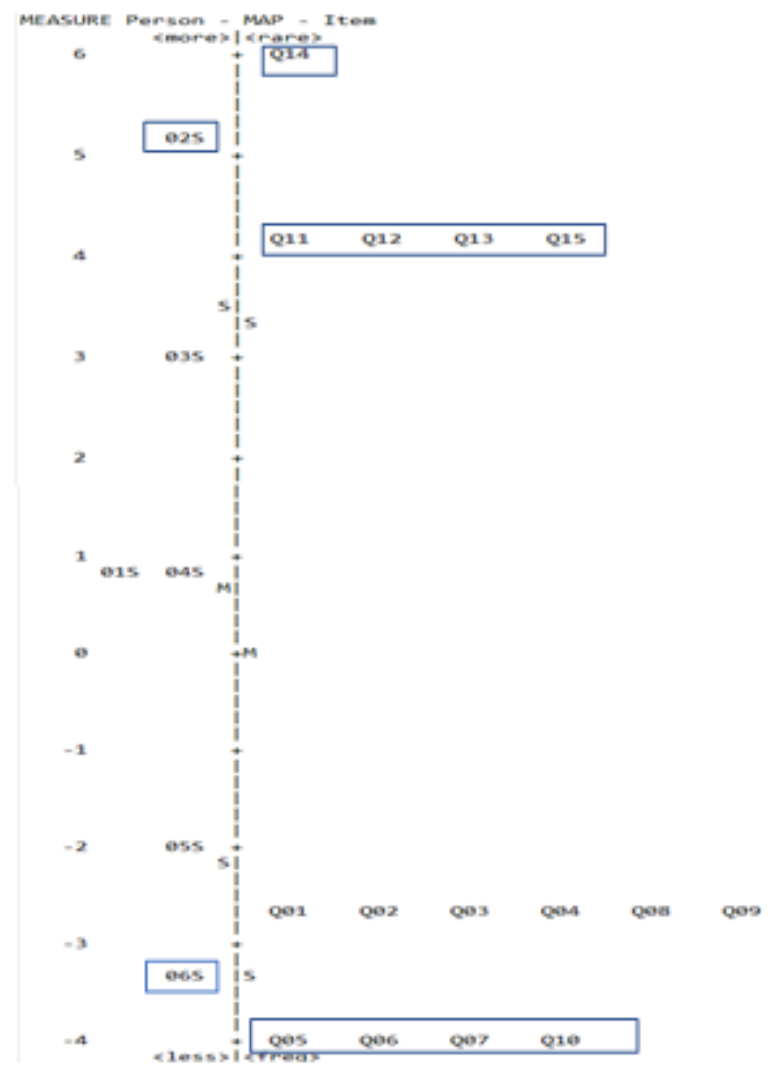

Fig. 4. Score of students' conceptual understanding.
It indicates that students' conceptual understanding about these concepts developed through Dunia Hidrokarbon games, but the concept of structural isomers and position isomers is not developed. Then we used Rasch analysis to identify students' conceptual understanding.

Fig. 3 shows the reliability of the individual, the reliability of the object, and the Cronbach alpha score. Fig. 3 confirms the importance of the person reliability 0.78 , which is the person reliability in the good enough category. While the importance of item reliability 0.76 and 0.82 , which is the item reliability in the good category. In addition, the Cronbach alpha value of 0.77 included a good category.

Analysis scores of students' conceptual understanding shown on Fig. 4. It demonstrates that respondent with code $02 \mathrm{~S}$ have the maximum conceptual understanding, but respondent with code $06 \mathrm{~S}$ have the minimum conceptual understanding about hydrocarbons topic. Items with code Q14 no one can answer correctly, and items with codes Q11, Q12, Q13, and Q15 are only answered correctly by one respondent. This result indicates that the concept of structural isomers and position isomers has not been understood by students.

This result is relevant to other research that isomerism is one of chemistry concept that students have limited to understood [20,21].

\section{B. Students' Critical Thinking}

The second study calculates the percentage of students' critical thinking. The purpose is to investigate the percentage of students who answered correctly for critical thinking items. Table 3 shows the percentage of students' critical thinking.

TABlE III. Percentage of Students' Critical Thinking

\begin{tabular}{|c|l|c|}
\hline No. & \multicolumn{1}{|c|}{ Critical Thinking Abilities } & Average Percentage \\
\hline 1. & Analyzing arguments & $25 \%$ \\
\hline 2. & $\begin{array}{l}\text { Asking and answering questions } \\
\text { of clarification and challenge }\end{array}$ & $0 \%$ \\
\hline 3. & Deciding on an action & $98 \%$ \\
\hline 4. & Focusing on a question & $100 \%$ \\
\hline
\end{tabular}

Based on the data in TABLE III it can be seen that the average percentage of critical thinking abilities deciding on an action and focusing the question more than $75 \%$. However, the average percentage of critical thinking abilities analyzing arguments and asking and answering questions of clarification and challenge is less than $75 \%$. It indicates that critical thinking abilities deciding on an action and focusing on a question can be developed, but analyzing arguments and asking and answering questions of clarification and challenge can't be developed through Dunia Hidrokarbon.

Critical thinking ability asking and answering questions of clarification and challenge are not developed through the Dunia Hidrokarbon. This case allegedly because as long as the student plays the Dunia Hidrokarbon, when the student has failed in forming hydrocarbons structure, they focus on the 
question "how to get the game done?" without thinking "why is the structure formed wrong?". While playing Dunia Hidrokarbon there was a conversation between students. While playing alkenes game, students (code 06S) asked to students (code 05S) "what about this second game? I built the structure but it didn't show up in the product." Then the student (code 05S) said "yes, me too". Student (code 02S) said "Try various possibilities, I was able to. That carbon atom has two bonds, attached two more single bond." It is alleged that student (code $02 \mathrm{~S}$ ) discovered this conception because he tried various possibilities. He answered incorrectly question number 2 which measures critical thinking ability of asking and answering questions of clarification and challenge. It is thought that the other students managed to complete the alkenes game because they tried various possibilities after hearing this conversation, without thinking about why carbon atoms with double bond can only have two more single bond. All students answer the question number 2 incorrectly.

\section{CONCLUSION}

Based on the research and discussions that have been described, it can be concluded that students' conceptual understanding and critical thinking can be developed through Dunia Hidrokarbon games. Students can understand concepts on hydrocarbon topics including: carbon atoms, determination of molecular formulas, structures, and names of alkanes, alkenes, and alkynes through Dunia Hidrokarbon games, but they do not understand the concept of structural isomers and position isomers. Students' critical thinking abilities focusing on a question and deciding on an action can be developed, but analyzing arguments, asking and answering questions of clarification and challenge can't be developed. This result suggested that Dunia Hidrokarbon on isomers part need to be revised.

\section{REFERENCES}

[1] R.D. Agustin, "Serious Games for Learning," in 2017 6th International Conference on Electrical Engineering and Informatics (ICEEI)., 2016, no. 2015, pp. 4-6, 2015

[2] M. Agarwal and S. Saha, "Learning chemistry through puzzle based game: Atoms to Molecule," in ICETA 2011 - 9th IEEE International Conference on Emerging eLearning Technologies and Applications, Proceedings, 2011, pp. 189-193.

[3] P. Kulju and M. Mäkinen, "Phonological strategies and peer scaffolding in digital literacy game-playing sessions in a Finnish pre-primary class," J. Early Child. Lit., vol. 0, no. 0, pp. 1-23, 2019.
[4] S. Seok and B. DaCosta, "Video games as a literacy tool: A comparison of players' and nonplayers' grades, reading test scores, and selfperceived digital reading ability," in Society for Information Technology \& Teacher Education International Conference 2019, no. 2016, pp. 777781,2019

[5] M. Checa-Romero, "Developing skills in digital contexts: Video games and films as learning tools at primary school," Games Cult., vol. 11, no. 5, pp. 463-488, 2016.

[6] C. Steinkuehler, "Video Games and Digital Literacies," J. Adolesc. Adult Lit., vol. 54, no. 1, pp. 61-63, 2010

[7] K.S. Arumugham, "Teachers effective role in developing the student' interest elementary schools," Int. J. Adv. Educ. Res., vol. 4, no. 3, pp. 05-11, 2019.

[8] F. Bavi, "The Effect of Using Fun Activities on Learning Vocabulary at the Elementary Level,” J. Lang. Teach. Res., vol. 9, no. 3, p. 629, 2018.

[9] J. Hartfill, "Word saber: An effective and fun VR vocabulary learning game," ACM Int. Conf. Proceeding Ser., pp. 145-154, 2020.

[10] N. Iten and D. Petko, "Learning with serious games: Is fun playing the game a predictor of learning success?," Br. J. Educ. Technol., vol. 47, no. 1, pp. 151-163, 2016

[11] S. Papadakis, "The use of computer games in classroom environment," Int. J. Teach. Case Stud., vol. 9, no. 1, p. 1, 2018

[12] N. Whitton and M. Langan, "Fun and games in higher education: an analysis of UK student perspectives," Teach. High. Educ., vol. 24, no. 8 , pp. 1000-1013, 2019.

[13] N. Srisawasdi and P. Panjaburee, "Implementation of Game-transformed Inquiry-based Learning to Promote the Understanding of and Motivation to Learn Chemistry," J. Sci. Educ. Technol., vol. 28, no. 2, pp. 152-164 2019

[14] K. Developing, "Developing 21st Century Chemistry Learning through Designing Digital Games,” J. Educ. Sci. Environ. Heal., vol. 4, no. 1, pp. 81-92, 2018.

[15] H.T. Hou and Y.C. Lin, "The Development and Evaluation of an Educational Game Integrated with Augmented Reality and Virtual Laboratory for Chemistry Experiment Learning," in Proceedings - 2017 6th IIAI International Congress on Advanced Applied Informatics, IIAIAAI 2017, pp. 1005-1006, 2017.

[16] S. Chen, S. Jamiatul Husnaini, and J.J. Chen, "Effects of games on students' emotions of learning science and achievement in chemistry," Int. J. Sci. Educ., vol. 42, no. 13, pp. 2224-2245, 2020.

[17] M.I. Cicchino, "Using game-based learning to foster critical thinking in student discourse," Interdiscip. J. Probl. Learn., vol. 9, no. 2, 2015.

[18] H. Lee, "Cooperation begins: Encouraging critical thinking skills through cooperative reciprocity using a mobile learning game," Comput. Educ., vol. 97, pp. 97-115, 2016.

[19] N.S. Sukmadinata, Metode penelitian. Bandung: Remaja Rosdakarya, 2012

[20] H.J. Schmidt, “Conceptual Difficulties with Isomerism,” J. Res. Sci. Teach., vol. 29, no. 9, pp. 995-1003, 1992

[21] M. Taagepera and S. Noori, "Mapping Students' Thinking Patterns in Learning,” Chem. Educ. Res., vol. 77, no. 9, pp. 1224-1229, 2000. 